\title{
Effectiveness of Physical Activity Circuit Model on Endurance of Elementary School Students
}

\author{
Apta Mylsidayu ${ }^{1 *}$, James Tangkudung ${ }^{2}$, and Achmad Sofyan Hanif ${ }^{3}$ \\ ${ }^{1}$ Universitas Islam “45” Bekasi, Indonesia ${ }^{2}$ Universitas Negeri Jakarta, Indonesia \\ "Corresponding author. Email: $\underline{\text { mylsidayu@ gmail.com }}$
}

\begin{abstract}
This study aims to determine the effectiveness of physical activity model based on circuit for endurance of elementary school students. The research method used is experiment with pretest-posttest control group design. Population and sample were 108 students, consisting of 49 students from the Elementary School of IT Darussalam Cikarang in Bekasi Regency, and 59 students from the Elementary School of AL-Azhar 17 Bintaro Tanggerang. Instrument test used was up and down bench tests that has been modified with the result of validity 0.974 and reliability 0.970 . The analysis technique used was IBM SPSS for Windows 21 with normality test using kolmogorof smirnov with result of asymp value. Sig (p) $>0.05$, and homogeneity test using Levene test with asymp result. sig $(\mathrm{p})>0.05$, which means the data is normal and homogeneous. The analysis test used in this research is the average difference test using t-test (paired t-test). The result of the experimental and control group showed a significant difference between pretest and posttest endurance of $0.00<0.05$. This indicates that there is an increasing in physical activity results both experimental and control groups. The magnitude of the difference in average increase in physical acitivity results between the experimental and control groups is $12.04>4.84$. That is, the increase of the experimental group is greater than the control group. So, there is a significant difference between pretest and posttest of endurance, but the physical activity model based on circuit is more effective than the control group.The recommendations that can be given based on the results of the study, include: (1) this physical activity model based on circuit can be used by physical education teachersto increase endurance student in the first class of elementary school, (2) for time effectiveness, the teacher must choose the same variety of tools to using in learning physical education based on circuit.
\end{abstract}

\section{Keywords: effectiveness, physical activity, circuit, endurance, elementary school students}

\section{INTRODUCTION}

Education as a human formation that lasts a lifetime. Physical education subjects are one of the subjects taught in elementary school. Physical education subjects are integrated part of education as a whole, aiming to develop physical aspects of physical fitness, movement skills, critical thinking skills, social skills, reasoning, emotional stability, moral actions, aspects of a healthy lifestyle and the introduction of a clean environment through physical activity, exercise, and selected health that is planned systematically in order to achieve national education goals [1]. Physical and health education is a process of education the which encourages, guides, develops, and builds Reviews their physical and spiritual Also the students health and environment for them to live in harmony and optimally, so they are able to do carry out their duty for themselves and national development [2].

Physical education taught in schools has a very important role which is to provide opportunities for students to be directly involved in various learning experiences through selected physical, sports and health activities carried out systematically. Debriefing the learning experience is directed at fostering better physical growth and psychological development, while forming a healthy and fit lifestyle throughout life [3].

At present, the enthusiasm of elementary school children to do physical activity shows symptoms of decline. This is due to the increasingly sophisticated technology in the modern era. Children prefer to hold the gadget or mobile phone to play games or watch videos, play play station, use a computer or the internet which results in many children who are less mobile because just sit in front of the television, mobile phone, or a computer, and in the end did not have a body a fit that is caused by a lack of motion or degenerative diseases. In addition, the physical activities of children in the open field are increasingly limited due to the increasingly densely packed subsidized and commercial housing developments. Indirectly, this has an impact on the low level of physical fitness of children, especially the biomotor component of endurance.

The current crisis in physical education is actually inseparable from the ineffectiveness of physical education 
learning in schools. The current management of physical education by teachers has not shown an effective and efficient direction because the discovery of physical education teachers in learning activities is monotonous, teacher-centered, using only a drill approach [4]. The effectiveness and efficiency of individual learning in schools is very dependent on the role of the teacher. Teachers as mentors in schools are expected to have creativity in developing learning models so students do not quickly feel bored [5].

\subsection{Physical activity}

Providing adequate physical activity for students and according to their needs is very important. Until now, there is no other way that can help students in schools actively move, cheerful, and fulfilled their movement needs in addition to physical activities. In order for elementary school students to be able to carry out adequate physical activities, various varied physical activities must be introduced so that through varied physical activities students gain good endurance to make them active and cheerful.

Active physical activity invites students to enjoy moving, doing various physical activities in various forms of play and game. Physical activity has a positive influence on students as long as it is practiced with the correct portion and concept of motion. In addition, structured, purposeful and meaningful physical activities can help students occur from various diseases while being able to develop healthy behaviors. Physical activities such as jumping, walking, throwing, cycling, jumping, and physical activities that develop students' physical motor potential are structured based on the planning of the teacher[6]. Physical activities such as throwing, jumping, walking, as mentioned above, are known as fundamental movements. Learning to move is the study of the processes involved in acquiring motor skills and variables that encourage or inhibit the acquisition of these skills.

The physical activities of elementary school low class students include basic movements (locomotor, nonlocomotor, manipulative), [7]. agility (Ministry of Education and Culture: 2013). Basic movements or in terms of motoric development in terms of fundamental movements involve the basic elements of certain movements of one movement. Examples of basic movements that need to be developed in childhood are running, jumping, shifting to the side, while manipulative motion can be throwing, catching, kicking, and pushing, all of which are part of further movements of more complex basic movements. Regarding the training model for basic motor skills is presented in table 1 below[8].

Based on the explanation of Table 1, the authors conclude the kinds of basic movements include walking, climbing, jumping, jumping, kicking, throwing, catching, bouncing the ball, hitting, swimming, running, rolling, sliding, twisting, pushing, pulling, stretching, stopping, changing direction/turning, crawling, prancing, galloping, gliding, and stepping-jumping, bending/bending/sitting, shut up and sway, rotate, dodge, and fall.
Table 1. Model exercises for basic motor skills

\begin{tabular}{llll}
\hline $\begin{array}{l}\text { Stage of } \\
\text { development }\end{array}$ & \multicolumn{1}{c}{$\begin{array}{c}\text { Form of } \\
\text { training }\end{array}$} & & Exercise \\
\hline Initiation & Preparatory & $\checkmark$ & Rolling \\
& exercises for & $\checkmark$ & Kicking \\
& skill acquisition & $\checkmark$ & Throwing \\
& & $\checkmark$ & Dribbling \\
& Simple balance & $\checkmark$ & Catching \\
& & & Walking on \\
& & $\checkmark$ & Jumping on \\
& & & $\begin{array}{l}\text { and off of low } \\
\text { objects }\end{array}$ \\
& & & catching \\
& Simple rhythm & $\checkmark$ & \\
& and reaction & & \\
time & & \\
& Simple spatial & $\checkmark$ & crawling and \\
& orientation and & & rolling \\
& sense of body & $\checkmark$ & somersault \\
& and limb & & front \\
& position & $\checkmark$ & throwing \\
& & $\checkmark$ & catching \\
\hline
\end{tabular}

The physical activity model carried out uses the concepts of play and learning. The physical activity model consists of: (a) 12 kinds of plane used for warming up (circles, semicircles, equilateral triangles, isosceles, square, pentagons, hexagons, parallelogram, rectangles, rhombus, kite, and trapezoid, (b) 24 letters (alphabet) for core learning, and (c) 10 numbers (0-9) for cooling down.

\subsection{Circuit}

The circuit training system was developed by Morgan and Adamson in 1953 at the University of Leeds England [9]. Circuit training is said to be a form of organizing methods of physical condition training to optimize physical abilities (Rothig and Grossing in [10].

As a training method, circuit training is designed by using training posts that stimulate the body's muscles to work alternately with setting certain training loads in accordance with the goals to be achieved. As a symbol of circuit training is a load that alternates with the main muscle groups in the exercise, namely the limb muscles, abdominal muscles, back muscles, shoulder muscles, and arms. The implementation of circuit training is usually used in several posts according to needs. That is, the teacher can make his own creations about the number of posts that will be used and what forms of physical activity are carried out in each post.

Physical activity is carried out using the circuit method. Students do some physical activity in each variation of the model during warm up, core learning, and cooling down.

\subsection{Endurance}

Endurance is the condition or condition of the body that is able to practice for a long time without experiencing excessive fatigue after completing the exercise[11]. In short, endurance exercise improves your body's ability to deliver 
the goods to your muscles so that they adapt, grow stronger, and become better at prolonged effort [12].

The purpose is to improve the ability of individuals to overcome fatigue during work activities, where fatigue can occur in the form of physical or psychological [13]. Endurance is needed to carry out activities in a long duration. Students who have good endurance will remain optimal in learning because they have a long time to go to fatigue. If the body feels tired, it will affect the brain's performance to concentrate.

Giving the right dose of circuit training it can be fun. Basically, this exercises having fun, as well as being able to have a little chat if necessary. This fact gives us a simple but effective concept for carrying out circuit training [14].

Based on the explanation above, this study aims to determine the effectiveness of physical activity model based on circuit for endurance of elementary school students.

\section{METHODOLOGY}

This research is a quasi-experimental research design with pretest-posttest control group design. Experimental research is an investigation designed so that the incident can be isolated from other influences. In simple terms, it can be said that the basic idea of experimental research is to try something and systematically observe what happens so that it can control the conditions of the experimental group and the control group [15].

The population is first class in elementary school AlAzhar 17 Bintaro and SDIT Darussalam Cikarang Bekasi Regency. The research sample consisted of 108 students, consisting of 49 students from the Elementary School of IT Darussalam Cikarang in Bekasi Regency, and 59 students from the Elementary School of AL-Azhar 17 Bintaro Tanggerang. The pretest and posttest used was up and down bench test that had been modified with the result of validity 0.974 and reliability 0.970 .

As for the procedure "up and down bench test" as follows: (1) purpose: to measure cardiorespiratory endurance, (2) tools: bench/box as high as $30 \mathrm{~cm}$, whistle, paper test result and pen, (3) procedure: (a) testor gives cue "ready", (b) when the whistle is blown, student rises up and down the bench until they can't do it anymore, (c) the legs must be straight when on the bench, (d) if going up with the right foot then go down with the right foot , and (4) assessment: the results of the test recorded are the numbers obtained when riding the bench completely.

The analysis technique used was IBM SPSS for Windows 21 with normality test using kolmogorof smirnov, and homogeneity test using Levene test. The analysis test used in this research is the average difference test using t-test (paired t-test).

\section{RESULTS AND DISCUSSION}

The sample of 108 students was divided into 2 groups; 54 experimental group students, and 54 control group students. The following is a description of the experimental and control group data.
Table 2. Description of experimental and control group data.

\begin{tabular}{lccccc}
\hline Group & $\mathrm{N}$ & $\begin{array}{c}\mathrm{Mi} \\
\mathrm{n}\end{array}$ & $\begin{array}{c}\mathrm{Ma} \\
\mathrm{x}\end{array}$ & $\begin{array}{c}\text { Mea } \\
\mathrm{n}\end{array}$ & $\mathrm{SD}$ \\
\hline Pre_test_experim & 5 & 14 & 34 & 23.2 & 6,309 \\
ent & 4 & & & 2 & \\
Post_test_experi & 5 & 20 & 52 & 35.2 & 6,824 \\
ment & 4 & & & 6 & \\
Pre_test_control & 5 & 20 & 65 & 36.9 & 11,74 \\
& 4 & & & 1 & 9 \\
Post_test_control & 5 & 25 & 65 & 41.7 & 12,20 \\
& 4 & & & 6 & 1 \\
\hline
\end{tabular}

Furthermore, the results of the normality test of research data for endurance variables use test kolmogorof smirnov can be seen in table 3 below.

Table 3. Endurance normality test results.

\begin{tabular}{ccc}
\hline Group & Pre test & Post test \\
\hline experiment & 0.068 & 0.169 \\
Control & 0.105 & 0.061 \\
\hline
\end{tabular}

Based on the above data, as can be seen in the experimental group that the pre test result was 0.068 and post test was 0.169 , while i n the control group, the pre test result was 0.105 and post test was 0.061 . So, it can be stated that the data is normally distributed because the result of $p>$ 0.05 . Then, homogeneity using levene test with the results can be seen in table 4 below.

Table 4. Endurance homogeneity test results.

\begin{tabular}{ccc}
\hline Group & Levene statistics & Sig. \\
\hline experiment & 0.003 & 0.955 \\
Control & 0.069 & 0.793 \\
\hline
\end{tabular}

The data above shows that the experimental group and the data variance control group were declared homogeneous because significant values were greater than 0.05 ( $\mathrm{p}>0.05$ ).

Furthermore, t-test is performed to determine whether there are differences between the resistance variable experimental and control groups. The results of the t test for endurance variables can be seen in table 5 below.

Table 5. Endurance t test results.

\begin{tabular}{clcc}
\hline & Group & $\mathrm{t}$ test & Sig. \\
\hline experiment & Post test's pre test & $-20,066$ & 0,000 \\
Control & Pre test_Post test & $-15,933$ & 0,000 \\
\hline
\end{tabular}

The result of the experimental and control group showed a significant difference between pretest and posttest endurance of $0.00<0.05$. To see the difference in the increase independent test sample $t$ test. Independent sample $t$ test aims to compare the average of two groups that are not related to each other, whether the two groups have the same average or not significantly [16].

Table 6 . The test results independent sample $t$ test endurance

\begin{tabular}{cccc}
\hline Group & Mean & F test & Sig. \\
\hline experiment & 12.04 & 28,176 & 0,000 \\
Control & 4.85 & & \\
\hline
\end{tabular}


Based on the test results, it can be seen the significance value is 0,000 . So, it can be concluded that $0,000<0.05$. So, $\mathrm{HO}$ is rejected. This indication that there is an increase in physical activity results in both experimental and control groups. The increase in the experimental group is 12.04 while in the control group is 4.85 . That is, the increase of the experimental group is greater than the control group. So, it can be concluded, there is a significant difference between pretest and posttest of endurance, but the physical activity model based on circuit is more effective than the control group.

Circuit based physical activity given to first grade elementary school students provides an increase in student endurance. Endurance is needed by students to overcome fatigue. Because fatigue will result in less optimal performance of the brain to learn. Fatigue is usually associated with weakness or the disappearance of the ability to react to others[13]. Fatigue can disrupt work, reduce productivity, increase errors, and potentially injury[17].

Model-based physical activity this circuit is one attempt to reduce boredom/saturated students, and foster students' curiosity about a wide variety of physical activities that are packed in the game.

\section{CONCLUSION AND SUGGESTION}

Based on the explanation above, it can be concluded that there is an increase physical activity significant both experimental and control

Groups $(0.00<0.05)$, but the physical activity model based on circuit is more effective than the control group. Thus, physical education teachers can use physical activity models with circuits for

learning variations so that students don't feel lazy and bored.The recommendations that can be given based on the results of the study, include: (1) this physical activity model based on circuit can be used by physical education teachersto increase endurance student in the first class of elementary school, (2) for time effectiveness, the teacher must choose the same variety of tools to using in learning physical education based on circuit.

\section{REFERENCES}

[1] Ayu, Cheni Chaenida Madu. "Desain dan media pembelajaran pendidikan jasmani, olahraga, dan kesehatan”. Gresik: Caremedia communication. 2018, pp 30-43.

[2] Firdaus, Kamal. "The implementation of physical and health education in school". International Seminar of Sport Culture and Achievement, ISSCA 2014 Proceedings Global Issues of Sport Science \& Sport Technology Development,Yogyakarta State University, 2014, pp 273-278.
[3] Ad'dien. "Perbandingan pengaruh latihan antara permainan kasti dengan permainan benteng terhadap peningkatan kesegaran jasmani dan vital kapasitas paru-paru murid SD Kecamatan Bacukiki Kota Pare-Pare"., Competitor, No.2, 2011,pp 60-81.

[4] Suherman, Ayi. "Pengembangan model pembelajaran outdoor education pendidikan jasmani berbasis kompetensi di sekolah dasar". Jurnal Penelitian, Vol. 9, No. 1, 2009, pp 1-16.

[5] Adi, Bayu Setyo. "Permainan kecil "sunda manda" sebagai alternatif bermain anak usia dini". Dinamika Pendidikan, No.01, Thn.XXI, 2014, pp 39-56.

[6] Muhyi, Muhammad., dkk. "learning through movement; senam bugar cerdas ceria berkarakter (BCCB)". Yogyakarta: Andi Offset. 2016, pp 2654

[7] Ministry of Education and Culture. Kurikulum 2013; kompetensi dasar Sekolah Dasar (SD)/Madrasah Ibtidaiyah (MI). Jakarta: Ministry of Education and Culture. 2013, pp 36-43.

[8] Bompa, Tudor O., \& Carrera, Michael. "Conditioning young athletes". USA: Human Kinetics. 2015, pp 30-43.

[9] Hidayat, Syarif. "Pelatihan olahraga; teori dan metodologi." Yogyakarta: Graha Ilmu. 2014, pp 47 54.

[10] Hanif, Achmad Sofyan. "Kepelatihan dasar sepak takraw". Jakarta: Rajawali Pers. 2015, pp 25-65.

[11] Harsono. "Latihan kondisi fisik". Bandung: FPOK UPI. 2001, pp 45-65.

[12] Sleamaker, Rob., \& Browning, Ray. "Serious training for endurance athletes ( $2^{\text {nd }}$ ed)". USA: Human Kinetics. 1996, pp 15-34.

[13] Mylsidayu, Apta \& Kurniawan, Febi. "Ilmu Kepelatihan Dasar". Bandung: Alfabeta. 2015, pp 44-53.

[14] Heldt, Ulli. "Tips for success circuit training"'. UK: Meyer \& Meyer Sport. 2001, pp 74-86.

[15] Yusuf, A Muri. "Metode penelitian: kuantitatif, kualitatif, dan penelitian gabungan". Jakarta: Kencana. 2017, pp 35-65.

[16] Santoso, Singgih. "Seri solusi bisnis berbasis TI menggunakan SPSS untuk statistik parametric". Jakarta: PT Elex Media Komputindo. 2005, pp 4550.

[17] Anies. "Penyakit akibat kerja; berbagai penyakit akibat lingkungan kerja dan upaya penanggulangnnya". Jakarta: PT Elex Media Komputindo. 2005, pp 135-145. 